\section{B A Institute of \\ YK Business Administration \\ 六下 \\ Karachi \\ Leadership and Ideas for Tomorrow}

Business Review

Volume 10 Issue 1 January - June 2015

$1-1-2015$

\title{
Revisiting compensating wage differentials: The evidence from employer-provided health insurance
}

Dan Qu

School of Economics and Trade, Hunan University, China

Follow this and additional works at: https://ir.iba.edu.pk/businessreview

Part of the Finance and Financial Management Commons, Health Economics Commons, and the Labor Economics Commons

(c) (1)

This work is licensed under a Creative Commons Attribution 4.0 International License.

\section{Recommended Citation}

Qu, D. (2015). Revisiting compensating wage differentials: The evidence from employer-provided health insurance. Business Review, 10(1), 5-20. Retrieved from https://doi.org/10.54784/1990-6587.1310

This article is brought to you by iRepository for open access under the Creative Commons Attribution 4.0 License and is available at https://ir.iba.edu.pk/businessreview/vol10/iss1/2. For more information, please contact irepository@iba.edu.pk. 


\title{
ARTICLE
}

\section{REVISITING COMPENSATING WAGE DIFFERENTIALS: THE EVIDENCE FROM EMPLOYER-PROVIDED HEALTH INSURANCE}

\author{
Dan Qu \\ School of Economics and Trade, Hunan University, China
}

\begin{abstract}
This paper uses 1996 and 2001 Survey of Income and Program Participation to examine the evidence for compensating wage differentials associated with employer-provided health insurance (EHI) in the United States. The results provide no evidence of a tradeoff between wages and EHI coverage. On the other hand, the results do suggest that employees who work in states with income taxes are more likely to receive EHI than those in states without income taxes. Fixed effects, first differencing and instrumental variable estimation are used to address the potential ability bias and endogeneity problems in wage models with EHI as an independent variable. While both fixed effects and first-differencing estimation provide evidence of a positive relationship between wages and EHI, validity tests cast doubt on fixed effects estimation. Instrumental variable estimates, however, provide no evidence of a tradeoff in either direction.
\end{abstract}

Key Words: Compensating Wage Differentials, Employer-Provided Health Insurance, First Differencing Estimation, Fixed Effects Estimation, Instrumental Variable Test

JEL No I13, I14, I15, J3,

\section{Introduction}

Employer-provided health insurance (EHI) is the primary type of insurance for most of the Americans. At least two thirds of Americans under 65 years of age have health insurance at their workplaces. Regardless of that, a continuous decline of the percentage of population with EHI was observed in the past decade. For instance, it was reported that the percentage of the population under 65 years of age covered by EHI decreased from $66.7 \%$ in 2000 to $65 \%$ in 2002 ; reaching at $61 \%$ in $2006 .{ }^{1}$

Declines in EHI coverage and the number of insured do not change the fact that EHI is still accepted by most employees in the United States which is mainly due to the advantage of tax deductibility. Employees benefit extensively from buying health insurance through workplaces.

Building on the situation aforesaid, this study explores the question that whether employees who obtained EHI earn a lower wage compared to those who lost EHI. The labor market outcome of having or losing EHI may have significant implications for health insurance reforms.

1. Information about of EHI is also introduced in the report on health in the United States, issued by the National Center for Health Statistics (2007). 
This study is based on the theory of compensating wage differentials. The pertinent theory was first suggested in the work of "The Wealth of Nations" (Smith, 1776). In a competitive labor market, an employer provides both pecuniary and non-pecuniary wages to workers. The non-pecuniary wage includes many aspects of a job; such as environment, location, how dangerous the work is, and all forms of benefits (vacation, pension, health insurance, etc.). Assuming that employees are all alike and that all jobs are identical, compensation packages for employees will locate on the same downward sloping budget constraint line. As a result, an employee who chooses a job offering higher health insurance coverage does so at the expense of giving up a certain amount of pecuniary wage. That is to say, the employer will pass at least a part of the cost of providing health insurance onto the employee in the form of a lower wage. An employee's willingness to give up some pecuniary wage and accept better health insurance critically depends on how much she values this health insurance. If the employee attaches higher value to EHI than to the amount of money she gives up, the cost may be passed wholly onto the employee. If the employee has other sources of health insurance, such as obtaining health insurance through his spouse, she may value the health insurance less; thus, the employer may bear some costs for providing the health insurance.

This study aims to contribute to the existing literature by empirically examining compensating wage differentials associated with EHI using the data from the Survey of Income and Program Participation (SIPP). First, SIPP is a nationally representative, longitudinal survey that provides extensive information on labor market behavior and health insurance status. Specifically, it not only collects information on whether the respondent has EHI, but also on the amount the employer pays for the health insurance and whether the employee obtains the health insurance through his/her dependent's or through her own employer. ${ }^{2}$ Second, this paper discusses the advantages and disadvantages of available empirical methodologies employed in studying compensating wage differentials.

This paper includes the following sections: the next section highlights literature review, section III sets up the empirical specification, section IV shows the discussion of data, while section V propounds empirical results. Section VI concludes the paper.

\section{Empirical Evidences from Previous Studies}

Most empirical studies previously carried out on compensating wage differentials associated with health insurance find that results are either insignificant or contradictory to the theory (Leibowitz, 1983; Woodberry, 1983; Eberts and Stone, 1985; Monhiet et al., 1985; Gruber and Krueger, 1990; Royalty, 2000; Jensen and Morriesty, 2001; Baiker and Chandra, 2005). A common explanation for the contradiction is the omission of worker's personal ability. OLS estimation is criticized by researchers for failing to capture workers' unobserved characteristics. However, the evidence to support the theory from fixed effects and two-stage least squares (2SLS) estimation is also fairly limited.

2. SIPP asks respondents "Did ...'s employer/union pay all, part, or none of the premium of the plan?" 
There are two critical problems generally found in previous studies. One is the data problem. Some studies use aggregated data (Woodbury, 1983; Gruber and Krueger, 1990; Gruber, 1994; Royalty, 2000), which tends to omit individual specific characteristics. The other problem is the application of OLS estimation. It has been discussed extensively that OLS estimation cannot capture all of a worker's unobserved characteristics (Brown, 1980, Duncan and Holmlund, 1983, Jensen and Morriesy, 2001, Simon, 2001; Miller, 2004, Olson, 2002, Baiker and Chandra, 2005). As an addition, this study uses a national longitudinal data set - SIPP to exploit individual level information in estimating the differential, and compares fixed effects estimates to the first-differencing and instrumental variable estimates.

\section{Empirical Specification}

The empirical estimation model is based on a human capital earnings model augmented with measurement of an employee's health insurance coverage.

$$
W_{i t}=f\left(X_{i t}, E H I_{i t}, u_{i t}\right)
$$

where $\mathrm{W}$ is the hourly wage rate for worker $i$ at time $\mathrm{t}, X$ is a set of individual characteristics that determines one's wage, EHI is a vector of the worker's health insurance coverage, and u is a stochastic error term. The wage equation used in this study is log linear.

$$
\log \left(W_{i t}\right)=X_{i t} \beta+E H I_{i t} \gamma+\alpha_{i}+u_{i t}
$$

where $i$ indicates an individual. The problem in estimating equation 2 is that we may not observe all $X^{\prime}$ s. Some of the individual characteristics are observable (such as race, gender, age, etc.) and some are not (such as worker's intelligence, ability, etc.). The unobserved timeconstant worker specific characteristic (such as $\alpha_{i}$ ) can bias the OLS estimation of $\gamma$ in 1 due to a possible correlation between these omitted variables and the worker's fringe benefits.

As a result, $\operatorname{COV}\left(E H I_{i t}, u_{i t}\right) \neq 0$. An employee with higher ability typically earns a higher wage and receives better health insurance given that all workers' other characteristics are alike. Therefore, if the unobserved characteristics are positively correlated with the wage level, $\gamma$ will be less negative and even positive. However, it is almost impossible to precisely measure these unobserved characteristics. This is a problem that cross-sectional data and OLS estimation encounter and cannot solve.

One solution to the problem is to apply fixed effects estimation. The fixed effects estimation takes away these unobserved and time-constant characteristics by including a dummy variable and captures variation within each individual. Thus, by taking into consideration the covariance between health insurance coverage and unobserved variables, we can eliminate the bias in estimation.

On the basis of this consideration, the first-differencing method is also proposed in this study. The first-differencing method also eliminates the worker's unobserved characteristics. Compared to the fixed effects estimation, this method captures the changes in the log hourly wage and health insurance coverage from one period to the next. It estimates 
whether the hourly wage increases when an employee gains EHI. A negative coefficient of the change in health insurance coverage indicates that getting better health insurance benefit lowers the hourly wage. Therefore, compared to demeaning explanatory variables in the fixed effects estimation, the first-differencing estimation assumes faster adjustment of the wage to changes in EHI. In this case, the first-differencing estimation could be more appropriate than the fixed effects estimation.

Besides the fixed effects and the first-differencing estimation, an instrumental variable (IV) test is also applied in this study to solve the endogeneity problem. Valid instruments are required to be uncorrelated with the error term (unobserved personal characteristics), but be correlated with endogenous variable (an employee's EHI status). In order to see the compensating wage differentials for working wives, instruments in this study include husband's EHI status, education level, union status and firm sizes.

\section{Data}

This study uses 1996 and 2001 SIPP panel data and includes employees who work at private firms that are for profit and whose ages are between 25 and $65 .{ }^{3}$ The dependent variable is the logarithm of the hourly wage at the current main job. This study uses information on the primary job. In order to protect the respondent's confidentiality, publicly used data on hourly wages and monthly wages in SIPP are top-coded, which follows a complex procedure. ${ }^{4}$ This study applies the mean above the top-code to top-coded values. The mean above the top-code is estimated by the lognormal distribution provided by Boushey (2006). ${ }^{5}$ Then hourly wage rate can be calculated. ${ }^{6}$ Hourly wages that are less than $\$ 1$ are excluded in this study.

EHI is a dummy variable, which equals " 1 " if covered by employer-provided health insurance and " 0 " otherwise. Personal information includes gender, race, marital status, age,

3. SIPP is a set of longitudinal survey data first collected in 1984 by the US Census of Bureau. Each panel of the survey is randomly divided into four groups. Each group is interviewed in a separate month. The same group is interviewed every four month, which is called a wave. Information in SIPP falls in two categories: core and topical. Core data includes information collected in every interview, and less frequently asked questions are collected in topical modules.

4. Hourly wages are top-coded at $\$ 30$ dollars, and monthly wages are top-coded at $\$ 12,500$ per month or 50,000 for four months. Any wage that is greater than the "acceptable threshold" will be assigned a value either equal to the threshold or coded in terms of the respondent's gender, race etc.

5. In "SIPP user notes", Boushey (2006) lists means above top-codes for both monthly wage and hourly wage. Two results are estimated by lognormal and Pareto distributions and one is calculated by the formula provided by the US Census Bureau. The mean provided by the US Census is much higher than the other two. This study chooses the mean estimated by lognormal distribution.

6. Hourly wage rate is calculated by $\left(\frac{S}{4.2 H}\right)$, where $\mathrm{S}$ is the monthly wage rate and $\mathrm{H}$ is total hours worked per week. 
and years of education. SIPP provides information on the highest grade employees attended. I apply the second reconciling strategy on educational-attainment questions introduced by Jaeger (1997) and recode these variables into how many years of education each employee attained. It ranges from 0 (didn't go to school at all) to 20 years (professional and Ph.D).

Labor market consequence variables include information on industry, occupation and firm sizes, part-time or full- time working schedule, and union membership. Individual's industry and occupation are coded in accordance with CPS system. Both include 14 categories. Full time workers are defined as those who work 35 hours or more per week ${ }^{7}$. Dummy variable "CHAGE" is " 1 " if the employee has ever changed jobs since last and " 0 " otherwise.

This study also includes year and state dummy variables. Seven year-dummy variables ${ }^{8}$ capture the general changes in wages due to inflation and any specific shocks in a certain year. State dummies help to pick up differences in the cost of living across states. More importantly, generosity of compensation may be differently correlated with the wage level across states. An interaction term between EHI and union status is included to test the effect of unionization on compensating wage differentials for EHI. The second interaction term between married and EHI included is to test whether married couples may tradeoff wages and EHI differently. The third interaction term is between "JBCHANGE" and EHI to examine whether an employee who has ever changed the job and gained EHI may compensated with a lower wage level.

Besides the estimation of wage equation, this study also examines factors that may affect the probability that an individual employee obtains EHI at the workplace. In particular, the impact of state income taxes is examined. An income tax $t$ is a dummy variable with " 1 " referring to states with income tax and " 0 " without income tax. A linear probability test is conducted in which the dependent variable EHI with " 1 " referring to having EHI and " 0 " otherwise.

\section{Results}

\section{OLS, Fixed Effects and First-differencing estimation.}

In table 2, EHI is significantly and positively correlated with wages, but the magnitude is smaller in first-differencing estimation. In first-differencing estimation, independent variables are changes of variables from the last period. The dependent variable is the change of an employee's log hourly wage. A significant positive estimate of EHI indicates that gaining EHI increases the growth rate of one's hourly wage by $2.4 \%$. Changing the jobs lowers the growth rate of one's wage. The growth rate of wages for elder workers is higher than that for younger workers, but age has a decreasing marginal effect on the growth rate of wages.

7. Refer to CPS and American Time Use Survey.

8. Year dummy variables include years from 1996 to 1999, and from 2001 to 2003. This is an unbalanced panel data. The 2001 survey didn't finish all interviews that are supposed to be 12 waves, due to a funding problem. 
Table 2. Estimation of log hourly wage (comparison of OLS and FE and FD)

\begin{tabular}{|c|c|c|c|}
\hline IV & $\begin{array}{l}\text { OLS } \\
(1)\end{array}$ & $\begin{array}{l}\text { FE } \\
(2)\end{array}$ & $\begin{array}{l}\text { FD } \\
(3)\end{array}$ \\
\hline EHI & $\begin{array}{c}.207 * * * \\
(.006)\end{array}$ & $\begin{array}{c}.068 * * * \\
(.009)\end{array}$ & $\begin{array}{l}.024 * * \\
(.010)\end{array}$ \\
\hline Union member & $\begin{array}{c}.131 * * * \\
(.003)\end{array}$ & $\begin{array}{c}.016^{* * *} \\
(.006)\end{array}$ & $\begin{array}{c}.003 \\
(.006)\end{array}$ \\
\hline Firm with 25-99 employees & $\begin{array}{l}.013 * * \\
(.007)\end{array}$ & $\begin{array}{l}-.007 \\
(.009)\end{array}$ & $\begin{array}{l}-.021 * \\
(.012)\end{array}$ \\
\hline Firm with $100+$ employees & $\begin{array}{c}.071 * * * \\
(.005)\end{array}$ & $\begin{array}{c}.005 \\
(.008)\end{array}$ & $\begin{array}{l}-.007 \\
(.011)\end{array}$ \\
\hline changed jobs & -- & -- & $\begin{array}{c}-.154 * * * \\
(.006)\end{array}$ \\
\hline Male & $\begin{array}{c}.205 * * * \\
(.002)\end{array}$ & -- & -- \\
\hline African American & $\begin{array}{c}-.029 * * * \\
(.006)\end{array}$ & -- & -- \\
\hline White & $\begin{array}{c}.040 * * * \\
(.005)\end{array}$ & -- & -- \\
\hline Age & $\begin{array}{l}.048 * * * \\
(.0008)\end{array}$ & $\begin{array}{c}.113^{* * *} \\
(.005)\end{array}$ & $\begin{array}{l}.018 * * \\
(.007)\end{array}$ \\
\hline Age square & $\begin{array}{l}-.0005 * * * \\
(9.46 \mathrm{e}-06)\end{array}$ & $\begin{array}{c}-.0008 * * * \\
(.00006)\end{array}$ & $\begin{array}{c}-.0002 * * * \\
(.00008)\end{array}$ \\
\hline Married & $\begin{array}{c}.069 * * * \\
(.002)\end{array}$ & $\begin{array}{l}.017 * * \\
(.006)\end{array}$ & $\begin{array}{c}.010 \\
(.008)\end{array}$ \\
\hline Education & $\begin{array}{l}.058 * * * \\
(.0005)\end{array}$ & -- & -- \\
\hline Intercept & $\begin{array}{c}.201 * * * \\
(.028)\end{array}$ & $\begin{array}{c}-.745 * * * \\
(.132)\end{array}$ & $\begin{array}{l}.020 * * \\
(.0008)\end{array}$ \\
\hline No. of obs & 210360 & 210360 & 152904 \\
\hline
\end{tabular}

Standard errors in parentheses

$* * * \mathrm{p}<0.01, * * \mathrm{p}<0.05, * \mathrm{p}<0.1$

This study follows the test of strict exogeneity in an expanded equation proposed by Wooldridge (2002) to test the validity of the two estimations. The results show that the firstdifferencing estimation is more appropriate than the fixed effects estimation.

\section{Compensating Wage Differentials by Age and Gender Groups}

With the knowledge that first-differencing estimation is more appropriate, table 3 and table 4 present first-differencing estimates by age and gender. The results in table 3 indicate that among middle-aged employees (age $35 \sim 54$ ), there is a positive correlation 
between wage and health insurance. The estimates for younger employees and elder employees show no correlation between wages and health insurance benefits. The age differences between group (1) and (2) $(t=2.18)$ and group (1) and (3) $(t=2.22)$ are both significant. Therefore, compared to younger employers (age $25 \sim 34$ ), middle-aged employees are more likely to gain both higher wages and better health insurance benefits. Age differences between group (2) and (4) $(t=1.13)$ and (3) and (4) $(t=1.25)$ are insignificant at $5 \%$ level.

Table 3. First-differencing estimation by age group

\begin{tabular}{|c|c|c|c|c|}
\hline \multirow[b]{3}{*}{ IV } & \multicolumn{4}{|c|}{ Dependent variable $=\Delta \log$ (hourly wage) } \\
\hline & $25-34$ & $35-44$ & $45-54$ & $55-65$ \\
\hline & (1) & (2) & (3) & (4) \\
\hline \multirow[t]{2}{*}{$\Delta_{\mathrm{EHI}}$} & .026 & $.031^{*}$ & $.037^{*}$ & -.001 \\
\hline & $(.018)$ & $(.019)$ & $(.022)$ & $(.021)$ \\
\hline \multirow[t]{2}{*}{$\Delta$ union } & .017 & .007 & -.004 & -.016 \\
\hline & $(.012)$ & $(.009)$ & $(.010)$ & $(.016)$ \\
\hline \multirow{2}{*}{$\begin{array}{l}\Delta \text { firm with 25-99 } \\
\text { employees }\end{array}$} & -.028 & $-.040 * *$ & .005 & -.014 \\
\hline & $(.023)$ & $(.020)$ & $(.021)$ & $(.033)$ \\
\hline \multirow{2}{*}{$\begin{array}{l}\Delta \text { firm with } 100+ \\
\text { employees }\end{array}$} & -.005 & -.030 & -.004 & .034 \\
\hline & $(.020)$ & $(.019)$ & $(.020)$ & $(.029)$ \\
\hline \multirow[t]{2}{*}{ Changing jobs } & $-.157 * * *$ & $-.157 * * *$ & $-.168 * * *$ & $-.126^{* * *}$ \\
\hline & $(.011)$ & $(.012)$ & $(.014)$ & $(.017)$ \\
\hline \multirow[t]{2}{*}{$\Delta$ married } & .016 & -.022 & $.055^{* * *}$ & -.031 \\
\hline & $(.012)$ & $(.015)$ & $(.020)$ & $(.049)$ \\
\hline \multirow[t]{2}{*}{$\Delta_{\text {Age }}$} & -.012 & .037 & -.033 & -.146 \\
\hline & $(.037)$ & $(.039)$ & $(.055)$ & $(.090)$ \\
\hline \multirow[t]{2}{*}{$\Delta_{\text {Age square }}$} & .0002 & -.0005 & .0004 & .001 \\
\hline & $(.0006)$ & $(.0005)$ & $(.0006)$ & $(.0008)$ \\
\hline \multirow[t]{2}{*}{ Intercept } & $-.128 * * *$ & $-.138 * * *$ & -.151 & -.115 \\
\hline & $(.011)$ & $(.012)$ & $(.014)$ & $(.017)$ \\
\hline No. of obs & 40907 & 50957 & 41508 & 19532 \\
\hline
\end{tabular}

Standard errors in parentheses

$* * * \mathrm{p}<0.01, * * \mathrm{p}<0.05, * \mathrm{p}<0.1$

The results in table 4 indicate that a male employee tends to obtain both a higher wage and better health insurance. There is no correlation between wages and health insurance for a female employee (column 2). However, the gender difference is insignificant $(t=.030)$. 
Table 4. First-difference estimation by gender

\begin{tabular}{|c|c|c|}
\hline & \multicolumn{2}{|c|}{ Dependent variable $=\Delta \log ($ hourly wage $)$} \\
\hline IV & $\begin{array}{c}\text { Male } \\
(1)\end{array}$ & $\begin{array}{c}\text { Female } \\
(2)\end{array}$ \\
\hline$\Delta \mathrm{EHI}$ & $\begin{array}{l}.027 * \\
(.014)\end{array}$ & $\begin{array}{c}.021 \\
(.014)\end{array}$ \\
\hline$\Delta_{\text {union }}$ & $\begin{array}{l}.001 \\
(.007)\end{array}$ & $\begin{array}{l}.005 \\
(.009)\end{array}$ \\
\hline$\Delta$ firm with 25-99 employees & $\begin{array}{l}-.024 \\
(.016)\end{array}$ & $\begin{array}{l}-.021 \\
(.018)\end{array}$ \\
\hline $\begin{array}{l}\Delta \text { firm with } 100+\text { employees } \\
\text { changing jobs }\end{array}$ & $\begin{array}{l}-.009 \\
(.014) \\
-.165 \\
(.009)\end{array}$ & $\begin{array}{c}-.005 \\
(.016) \\
-.140 * * * \\
(.009)\end{array}$ \\
\hline$\Delta_{\text {Age }}$ & $\begin{array}{l}.020 * * \\
(.010)\end{array}$ & $\begin{array}{l}.014 \\
(.011)\end{array}$ \\
\hline$\Delta$ Age square & $\begin{array}{c}-.0002 * \\
(.0001)\end{array}$ & $\begin{array}{l}-.0002 * \\
(.0001)\end{array}$ \\
\hline$\Delta$ married & $\begin{array}{l}.0005 \\
(.011)\end{array}$ & $\begin{array}{c}.022 \\
(.012)\end{array}$ \\
\hline Intercept & $\begin{array}{c}.018 * * * \\
(.001)\end{array}$ & $\begin{array}{c}.023 * * * \\
(.001)\end{array}$ \\
\hline No. of obs & 90274 & 62630 \\
\hline
\end{tabular}

Standard errors in parentheses

$* * * \mathrm{p}<0.01, * * \mathrm{p}<0.05, * \mathrm{p}<0.1$

\section{First-difference Estimation with Interaction Terms.}

In order to identify possible factors that might contribute to a positive correlation between wages and EHI coverage, three interaction terms are included. Using firstdifferencing estimation, these effects are examined. The results in table 5 indicate that changing jobs contribute to a positive correlation between hourly wage rise and EHI coverage.

Table 5. First-difference estimation with interaction terms

\begin{tabular}{lcccc}
\hline \hline Variables & $(1)$ & $(2)$ & $(3)$ & $(4)$ \\
\hline EHI & $.024^{* *}$ & .015 & $.024^{* *}$ & .015 \\
& $(.010)$ & $(.010)$ & $(.010)$ & $(.010)$ \\
$\Delta$ Union membership * $\Delta$ EHI & -.090 & & & -.090 \\
& $(.057)$ & & & $(.056)$ \\
changing jobs* $\Delta_{\text {EHI }}$ & & $.072 * *$ & & $.072^{* *}$ \\
$\Delta_{\text {Married }} \Delta_{\text {EHI }}$ & & $(.032)$ & & $(.032)$ \\
& & & .065 & .065 \\
No. of obs. & & & $(.088)$ & $(.085)$ \\
\hline
\end{tabular}

Standard errors in parentheses

$* * * \mathrm{p}<0.01, * * \mathrm{p}<0.05, * \mathrm{p}<0.1$ 
The Impact of Income Taxes on the Probability of Receiving EHI.

Table 6 presents results of the probability that an employee obtains EHI. The empirical results (column 1) show that an employee who lives in a state with income taxes is $10 \%$ more likely to have EHI. Union membership, being married, working in a larger firm and working longer hours increase the probability of having EHI. The likelihood of having EHI increases as age increases, but eventually decreases with increasing age. Female employees are more likely to have EHI than male employees. This may be because of a greater demand for EHI by women; as they tend to make more use of the health care system at younger ages. The results also show that higher education is associated with a lower likelihood of having EHI. This may be because more educated employees pay more attention to the cost of health insurance than less educated ones, and so are less likely to sacrifice pay for EHI. In any case, this is a surprising result; education increases wages which is generally associated with a higher probability of having EHI.

In column 2, an interaction term between gender and the education level is added to the regression to indentify any differences between female and more educated employees and others. The result indicates that female and more educated workers do not behave differently from others in having EHI. Column 3, 4 and 5 test the probabilities of obtaining EHI of married employees, husbands and wives. Results match well with those using the whole sample in column 1 .

\section{Estimation.}

Instrumental variable estimation is also a method used to alleviate omitted variable problems. Column 1 and 2 in table 8 used the same instruments that Olson used in his study. The results show that the EHI has no influence on wages, which is different from the results in Olsen's study. Before conducting other IV estimation, the weak instruments test and erogeneity test (in table 7) showed that that instrumental variables should include HEHI, HUNION, HSIZE, and HEDU. Column 6 and 7 suggest that instruments are not weak and the over-identification test does not reject the null hypothesis. When including SPEDU (column 8), exogeneity test suggests that SPEDU is an invalid instrument.

IV estimation of the whole sample and full-time working wives are presented in table 8. Following the discussion in Olson's paper (2002), the spouse's education level is included in the wage equation. Columns 3 to 5 use the sample of full-time working wives with three different sets of instruments. Columns 6 to 8 use the sample of all employees. Estimates for the two samples are very similar. When using the spouse's education as the only instrument, there is a positive correlation between the wage level and EHI coverage. When using the other two sets of instruments, estimates are insignificant. Therefore, there is no evidence of a connection between the wage level and EHI coverage.

First differenced IV and fixed effects IV estimation are also applied for full-time working wives. Estimates of EHI in both fixed effects IV and first differenced IV are negative but insignificant, especially in first differenced IV estimation the coefficient is even more negative. 


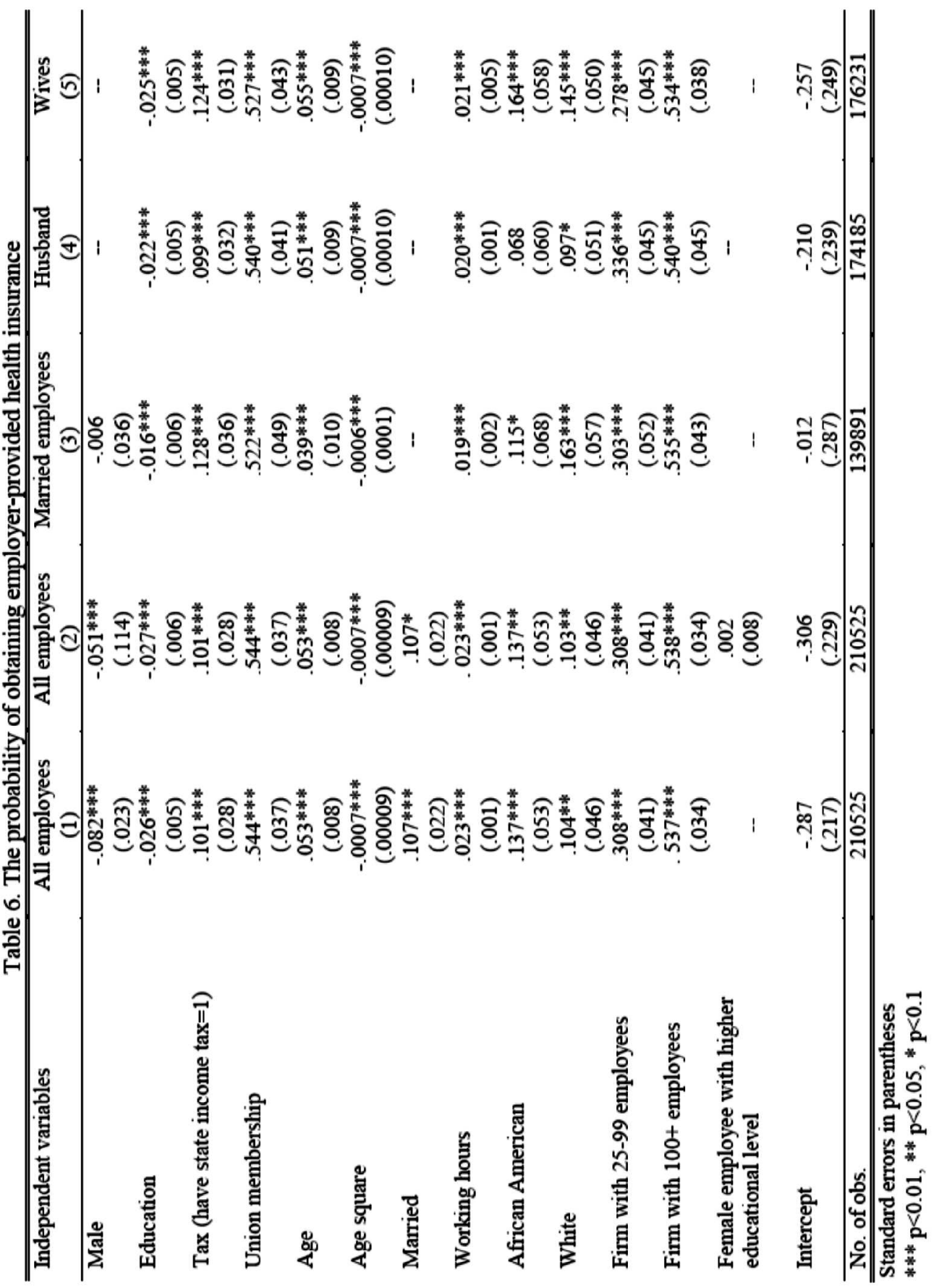



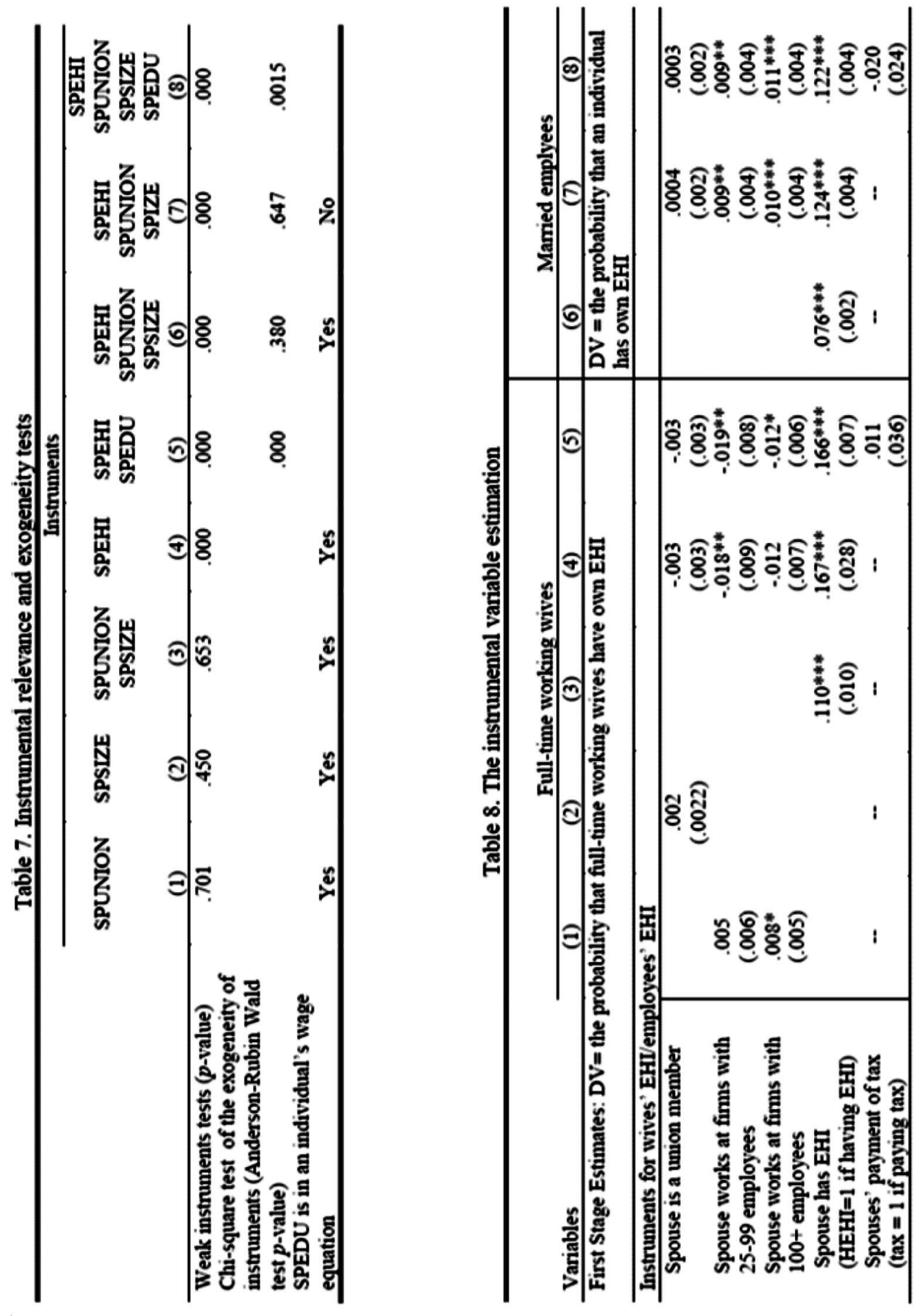


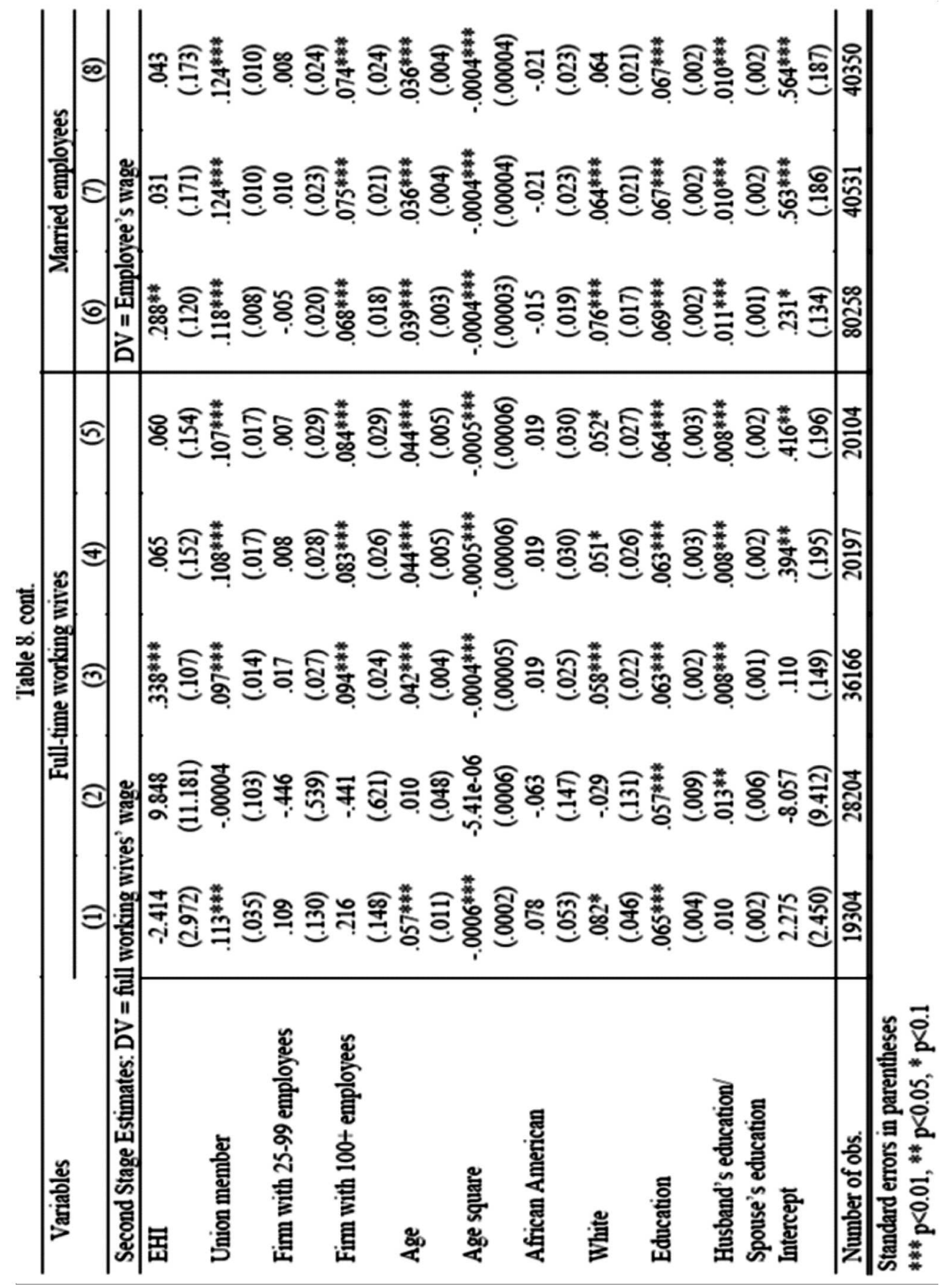




\section{Conclusions}

This study uses SIPP data to test compensating wage differentials associated with employer-provided health insurance. To solve the omitted variable problem, fixed effects estimation, first-differencing estimation, IV estimation, first differenced IV estimation, and fixed effects IV estimation methods are employed. Results of fixed effects and first-difference estimation lead to the conclusion that employees tend to receive higher wages when they gain EHI. A validity test of the two indicates that the first-differencing estimation is more appropriate than the fixed effects estimation. IV estimation, fixed effects IV estimation and first differenced estimation suggest that EHI has no influence on wages.

This study suggests that employees who live in states that collect income taxes are more likely to have EHI than those who live in states without income taxes. This could be because of the tax advantage from having EHI. Changing jobs contributes to a positive correlation between having EHI and the wage growth.

In the future study of compensating wage differentials, to uncover the correlation between wage and EHI coverage, it may be interesting to consider the following three aspects. First, it would be useful to consider information on employers' preferences of providing benefit packages. It is possible that an employer would prefer to provide a higher wage premium and better health insurance benefit in order to avoid worker's shirking. Second, it would be useful to apply continuous data for EHI coverage rather than the dummy indicator. Third, the tax rate information could also indicate the level and progressivity of the state tax system. 迷

\section{Acknowledgements}

This work was supported by Hunan University under Grant No. 531107022116 and China Scholarship Council under Grant No. 757234005.

\section{References}

Baicker, Katherine and Chandra, Amitabh. "The Labor Market Effects of Rising Health Insurance Premiums." NBER working paper, 2005.

Brown, Charles. "Equalizing Differences in the Labor Market." The Quarterly Journal of Economics, 1980, Vol.94, pp.113-134.

Boushey, Heather. "SIPP User Notes on Set D: Labor Market and Employment Outcomes." Washington, DC: Center for Economic and Policy Research, 2006.

Boushey, Heather and Schmitt, John. "Using Wage Data from the Survey of Income and Program Participation (SIPP)." Washington, DC: Center for Economic and Policy Research, 2004.

Currie, Janet and Madrian, Brigitte. "Health, Health Insurance and the Labor Market," in O. Ashenfelter and D. Card, ed. Handbook of Labor Economics, 1999, Vol.3, pp.3309-3415.

Daniel, Christophe and Sofer, Catherine. "Bargainin, Compensating Wage Differentials, and Dualism of the Labor Market: Theory and Evidence for France." Journal of Labor Economics, 1998, Vol. 16, No. 3, pp.546-575.

Davidson, R. and J. G. MacKinnon. "Estimation and Inference in Econometrics." New York: Oxford University Press, 1993. 
Duncan, Greg and Holmlund, Bertil. "Was Adam Smith Right After All? Another Test of the Theory of Compensating Wage Differentials." Journal of Labor Economics, Vol., 1983, pp.366-379.

Eberts, Randall W. and Stone, Joe A. "Wages, Fringe Benefits, and Working Conditions: An Analysis of Compensating Differentials.” Southern Economic Journal, 1985, Vol.52, pp. 274280 .

Gould, Elise. "Health Insurance Eroding for Working Families.” EPI briefing paper, 2006.

Gould, Elise. "The Chronic Problem of Declining Health Coverage: Employer-Provided Health Insurance Falls for Third Consecutive Year." Economic Policy Institute Issue Brief \#202, 2004.

Gruber, Jonathan. "The incidence of mandated maternity benefits." The American Economic Review. 1994, Vol.84, No.3, pp.622-641.

Gruber, Jonathan. "Health Insurance and the Labor Market." NBER working paper series, 1998.

Gruber, Jonathan and Krueger, Alan B. "The Incidence of Mandated Employer-Provided Insurance: Lessons from Workers' Compensation Insurance." Tax Policy and the Economy, 1991, Vol.5, pp.111-143.

Gruber, J. and J. Poterba "Fundamentai Tax Reform and Employer-Provided Health Insurance." in Henry J. Aaron and William G. Gale, ed., Economic Effects of Fundamental Tax Reform. 1996, pp.125-170.

Jaeger, David A. "Reconciling the Old and New Census Bureau Education Questions:

Recommendations for Researchers." Journal of Business and Economic Statistics, 1997, Vol.15, No.3, pp.300-309.

Jensen, Gail A. and Morrisey, Michael A. "Endogenous Fringe Benefits, Compensating Wage Differentials and Older Workers." International Journal of Health Care Finance and Economics, 1, 2001, pp.203-226.

Kletzer, L. "Job Displacement." Journal of Economic Perspectives, 1998, 12(1), pp.115-136.

Leibowitz, A. "Fringe Benefits in Employee Compensation," in Jack E. Triplett, ed., The Measurement of Labor Cost. Chicage: The University of Chicago Press.

Madrian, Brigitte C. "The U.S. Health Care System and Labor Markets," NBER working paper,2006.

Miller, Richard. "Estimating the Compensating Differential for Employer-Provided Health Insurance.” (2004)

Mincer, Jacob "Schooling, Experience, and Earnings," 1974, New York: Columbia University Press.

Monheit, A., Hagan, M. Berk and Farley, P. "The Employed and Uninsured and the Role of Public Policy." Inquiry, 1985, 22, pp.348-364.

Olson, Craig A. "Do Workers Accept Lower Wages in Exchange for Health Benefits?" Journal of Labor Economics, 2002, Vol.20, No.2, pp.91-114. 
Pear, Robert. "Gender Gap Discovered in Health Insurance." The San Diego Union Tribune. October $\quad 30, \quad 2008 \quad$ (http://legacy.signonsandiego.com/uniontrib/20081030/ news_ln30insure.html)

Royalty, Anne Beeson. "A Discrete Choice Approach to Estimating Workers' Marginal Valuation of Fringe Benefits." working paper, 2000.

Sheiner, Louise. "Health Care Costs, Wages, and Aging.” working paper, 1999.

Smith, R. S. "Compensating Wage Differentials and Public Policy: A Review." in N. Terleckyj, ed., Household Production and Consumption, New York: National Bureau of Economic Research, 1975.

Woodbury, Stephen A. "Substitution between Wage and Nonwage Benefits." The American Economic Review, 1983, Vol.73, No.1, pp.66-182.

Wooldridge, Jeffrey M. "Econometric Analysis of Cross Section and Panel Data." The MIT press, 2002.

\section{APPENDIX}

Literature on compensating wage differentials in health insurance

\begin{tabular}{|c|c|c|c|}
\hline Author & Data & Method & Result \\
\hline \multicolumn{4}{|c|}{ Compensating wage differentials for work characteristics } \\
\hline Brown (1980) & $\begin{array}{l}1966-71 \text { and } 1973 \text { NLS } \\
\text { Young men's sample } \\
\text { (470 observations) }\end{array}$ & $\begin{array}{l}\text { Fixed effects } \\
\text { estimation }\end{array}$ & $\begin{array}{l}\text { Positive but insignificant } \\
\text { correlation between wage } \\
\text { and job characteristics. No } \\
\text { significant improvement, } \\
\text { compared to level } \\
\text { estimation. }\end{array}$ \\
\hline $\begin{array}{l}\text { Duncan and } \\
\text { Holmlund(19 } \\
83)\end{array}$ & $\begin{array}{l}\text { Self-report survey of a } \\
\text { sample of Swedish men } \\
\text { in } 1968 \text { and } 1974\end{array}$ & $\begin{array}{l}\text { Fixed effects } \\
\text { estimation }\end{array}$ & $\begin{array}{l}\text { Compared to Brown's } \\
\text { results, their results (of } \\
\text { correlation between wage } \\
\text { and job characteristics) are } \\
\text { improved, although some } \\
\text { results are still } \\
\text { insignificant. }\end{array}$ \\
\hline \multicolumn{4}{|c|}{ Compensating wage differentials for fringe benefits } \\
\hline $\begin{array}{l}\text { Leibowitz } \\
\text { (1983) }\end{array}$ & $\begin{array}{l}1978 \text { RAND Health } \\
\text { Insurance Study, full- } \\
\text { time workers } \\
\text { observations) }\end{array}$ & OLS & $\begin{array}{l}\text { Positive and insignificant } \\
\text { correlation between health } \\
\text { insurance and wages }\end{array}$ \\
\hline $\begin{array}{l}\text { Woodbery } \\
(1983)\end{array}$ & $\begin{array}{l}\text { 1966-74 BLS survey } \\
\text { and a sample of } \\
\text { independent school } \\
\text { districts from the } 1977 \\
\text { Census of Governments }\end{array}$ & $\begin{array}{l}\text { Estimation of } \\
\text { indirect utility } \\
\text { function that } \\
\text { involves the } \\
\text { elasticity of } \\
\text { substitutability } \\
\text { of wage and } \\
\text { fringe benefits }\end{array}$ & $\begin{array}{l}\text { Wage and fringe benefits } \\
\text { are substitutes. The } \\
\text { elasticity of the } \\
\text { substitutability is greater } \\
\text { than 1. }\end{array}$ \\
\hline $\begin{array}{l}\text { Eberts and } \\
\text { Stone (1985) }\end{array}$ & $\begin{array}{lr}1972-73 & \text { and } 1976-77 \\
\text { full-time } & \text { elementary }\end{array}$ & $\begin{array}{l}\text { Fixed effects } \\
\text { estimation }\end{array}$ & $\begin{array}{l}\text { Negative and significant } \\
\text { correlation between health }\end{array}$ \\
\hline
\end{tabular}




\begin{tabular}{|c|c|c|c|}
\hline 216 & Volume 10 Number 1 & & January - June 2 \\
\hline & $\begin{array}{lr}\text { and } & \text { secondary } \\
\text { classroom teachers in } \\
\text { N.Y. }\end{array}$ & & benefits and wages \\
\hline $\begin{array}{l}\text { Monhiet et al. } \\
\text { (1985) }\end{array}$ & $\begin{array}{l}1977 \text { NMCES, full-time } \\
\text { workers }\end{array}$ & $\begin{array}{l}\text { OLS estimation } \\
\text { by occupation }\end{array}$ & $\begin{array}{l}\text { Positive correlation in most } \\
\text { occupations, professional } \\
\text { and technical workers } \\
\text { showed negative but } \\
\text { insignificant correlation. }\end{array}$ \\
\hline $\begin{array}{l}\text { Gruber and } \\
\text { Krueger } \\
(1990)\end{array}$ & $\begin{array}{l}1979-81 \text { and } 1987-88 \\
\text { CPS data, and } 1979-88 \\
\text { state-level employer } \\
\text { reported data from BLS }\end{array}$ & $\begin{array}{l}\text { OLS, first } \\
\text { differencing }\end{array}$ & $\begin{array}{l}\text { Insignificant results by } \\
\text { OLS estimation except for } \\
\text { truck drivers, }\end{array}$ \\
\hline $\begin{array}{l}\text { Gruber } \\
\text { (1994) }\end{array}$ & $\begin{array}{l}\text { CPS, states that passed } \\
\text { state maternity } \\
\text { mandates after } 1974 \\
\text { and federal mandates } \\
\text { after } 1978 \text { and states } \\
\text { that didn't }\end{array}$ & $\begin{array}{l}\text { Differences-in- } \\
\text { differences-in- } \\
\text { differences }\end{array}$ & $\begin{array}{l}\text { Negative and significant } \\
\text { correlation between wage } \\
\text { and mandated health } \\
\text { insurance for } 20-40 \\
\text { married women. }\end{array}$ \\
\hline $\begin{array}{l}\text { Sheiner } \\
\text { (1999) }\end{array}$ & $\begin{array}{l}\text { Matching the wage data } \\
\text { from } 1990 \text { and } 1991 \\
\text { March CPS with the } \\
\text { health care cost data } \\
\text { obtained from Milliman } \\
\text { and Robertson survey. }\end{array}$ & OLS & $\begin{array}{l}\text { Older worker suffers larger } \\
\text { decrease in wage than } \\
\text { young worker, result is } \\
\text { significant for male } \\
\text { workers, but insignificant } \\
\text { for female }\end{array}$ \\
\hline $\begin{array}{l}\text { Royalty } \\
(2000)\end{array}$ & $\begin{array}{l}\text { RWJ-EHIS (1993-94) } \\
\text { aggregated to firm-level }\end{array}$ & $\begin{array}{l}\text { Logit } \\
\text { estimation }\end{array}$ & $\begin{array}{l}\text { Negative and insignificant } \\
\text { correlation between wages } \\
\text { and health insurance }\end{array}$ \\
\hline $\begin{array}{l}\text { Jensen and } \\
\text { Morriesy } \\
(2001)\end{array}$ & $\begin{array}{l}1994 \text { and } 1998 \text { Health } \\
\text { and Retirement Survey }\end{array}$ & IV estimation & $\begin{array}{l}\text { Correlation between wage } \\
\text { and health insurance and } \\
\text { pension are negative and } \\
\text { insignificant. }\end{array}$ \\
\hline Simon (2001) & $\begin{array}{l}\text { 1984-2000 even year } \\
\text { DWS data }\end{array}$ & $\begin{array}{l}\text { Fixed effects } \\
\text { estimation }\end{array}$ & $\begin{array}{l}\text { Displaced worker who find } \\
\text { a new job gains wage when } \\
\text { having EHI, and loses } \\
\text { wage when losing EHI }\end{array}$ \\
\hline Olson (2002) & $\begin{array}{l}\text { March-June 1990-93 } \\
\text { CPS for full-time } \\
\text { working wives }\end{array}$ & IV estimation & $\begin{array}{l}\text { Full-time working wives } \\
\text { will accept jobs with health } \\
\text { insurance when wages } \\
\text { decrease by } 20 \% \text {. }\end{array}$ \\
\hline Miller (2004) & 1988-90 CEX & $\begin{array}{l}\text { Fixed effects } \\
\text { estimation }\end{array}$ & $\begin{array}{l}\text { Negative and significant } \\
\text { between the change in } \\
\text { wages and the change in } \\
\text { health insurance status }\end{array}$ \\
\hline $\begin{array}{l}\text { Baiker and } \\
\text { Chandra } \\
(2005)\end{array}$ & $\begin{array}{l}\text { Kaiser } \\
\text { Foundation }\end{array}$ & IV estimation & $\begin{array}{l}\text { Negative but insignificant } \\
\text { correlation between wages } \\
\text { and health insurance }\end{array}$ \\
\hline
\end{tabular}

